\title{
Interculturality or Government of Childhood? Challenges of Indigenous Child Care in Colombia
}

\author{
Vivian Lissette Ospina Tascón, Tatiana Calderón García, and Martin J. Packer
}

\begin{abstract}
Vivian Lissette Ospina Tascón (MA in psychology of cognition and learning, Facultad Latinoamericana de Ciencias Sociales, Buenos Aires) is an assistant professor at la Universidad San Buenaventura-Cali, Cali, Colombia. Email: vlospina@usbcali.edu.co

Tatiana Calderón García, MA in psychology, Universidad del Valle Cali, is a doctoral student and assistant professor at la Universidad de San Buenaventura-Cali, Cali, Colombia. Email: tcalderon@usbcali.edu.co

Martin J. Packer, PhD in developmental psychology, University of California, Berkeley, is an independent researcher in Bogotá, Colombia. He has taught at the Universidad de los Andes, Duquesne University, the University of Michigan, and the University of California, Berkeley. His principal interests are child development, cultural psychology, and qualitative research. He is the author of Child Development: Understanding a Cultural Perspective (SAGE, 2017). Email: mpacker@cantab.net
\end{abstract}

A global phenomenon is the reorganization of care for very young children. Institutions are replacing the context of family and community. Increasingly in Colombia young children spend hours each day in institutions directed by public policy and administrative guidelines. We explore, first, how research on this phenomenon adopts a reductionist perspective, a focus on "quality" and "outcomes" measured in ways that assume a Western axiology. Second, we consider how the institutionalization of childhood amounts to a "government" that imposes Western individualism. Third, we illustrate the tension created for childcare professionals and for Indigenous communities as their rights to make decisions about the best ways to care for children are threatened.

Key words: childcare; institutions; young children; government; Indigenous
A social phenomenon spreading across the world today is the reorganization of forms of care for very young children. In the past, what have prevailed are forms of care and education for children from birth to around 3 years of age in the context of their family and community. The trend today is one of the institutionalization of these children. In the South American nation of Colombia, babies, infants, and toddlers are spending many hours each day in institutions whose dynamics and functioning are directed primarily by public policy and administrative guidelines.

In this article we first explore the tendency for research on this phenomenon to adopt a reductionist perspective, in which the focus is on indications of "quality" and "outcomes" that are measured in ways that assume a Western axiology and ontology. Policies and political positions remain unexamined. Second, we propose that this institutionalization of the first years of childhood involves "government" which amounts to the inculcation of a particular way of being a person. Third, we show, in two examples from our research, how state intervention in the care and education of young children creates various kinds of tension for the professionals who work in institutions with young children, as well as for Indigenous communities, for whom it threatens to undermine not only their rights to make decisions about the best ways to care for their children but also their very existence.

Overall, we hope to contribute to a reflection on the challenges that are intrinsic to the institutional care of very young children and, above all, to explore the potential risks for children in Indigenous communities. 


\section{Institutionalized childcare in Colombia}

In 2012, UNESCO reported an increase of $40 \%$ in the number of young children enrolled in early institutional programs across the world (UNESCO, 2012). In Colombia, it is children in the lowest socioeconomic strata who attend programs offered by the state, while children in the higher strata are cared for at home. The most recent censuses indicate that of the 3.2 million children under 5 years of age in Colombia, 2.4 million are in conditions of economic vulnerability (Bernal, 2014). Some of these young children are in state child development centres, others are in hogares comunitarios and kindergartens in the private sector. Many are cared for by madres comunitarias, women who take children into their homes and who are recognized in their community for their compassion and commitment to the well-being of children (there are almost 70,000 in Colombia).

Colombia's public policy for childhood (Consejo Nacional de Política Económica Social, República de Colombia, 2007) is based on international guidelines and represents the government's commitment to improving comprehensive care for young children. The policy is implemented through the Estrategia de Atención Integral, a comprehensive plan that includes objectives related to nutrition, health, and healthy environments, educational practices that promote "integral development," restitution of rights, children's participation in decision making, promotion of citizen participation in the evaluation and implementation of policy, and ensuring that all children are registered and receive an identity document.

Achieving these objectives is the aim of three types of program, directed to the family, to institutions, and to communities respectively. Since 2016, there has also been a fourth type of program, the Modalidad Propia e Intercultural (Instituto Colombiano de Bienestar Familiar, 2016), directed to the country's ethnic and Indigenous peoples. The development of this fourth program follows principles established by the Colombian Constitution of 1991: the recognition of diversity, rights for all people without discrimination, and preservation of the languages and dialects of ethnic groups.

Overall, these programs have the following characteristics. With the exception of the fourth, they are designed mainly for children in urban settings. They are based on the assumption, arising from pediatrics, neurosciences, and conceptions of children's rights, that there is a universal pattern to children's psychological development. They are guided by the policies of global organizations such as the World Bank and UNICEF. They are implemented with the intention of respecting cultural diversity, but in fact they often fail to recognize the tensions and challenges they create for Indigenous communities. Consequently, they lack the conditions that would make viable a real dialogue among those who implement public policies and those who are the recipients.

The emphasis on interculturality arises from recognition of the fact that Colombia is a pluricultural country with an important percentage of Indigenous peoples who live in territories dispersed around the country. The census data for 2005 indicate that, of the total population of children between birth and 5 years old in Colombia, approximately $14.4 \%$ belong to an ethnic group. The Afro-descendant population represents $9.8 \%$ of the total, with 507,272 individuals. Of these, 3,679 are raizales (Indigenous peoples from Colombian islands of San Andrés, Providencia, and Santa Catalina), 663 are palenqueros (afrocolombianos from the Atlantic coast), and 502,930 are Afro-Colombian. In addition, 236,966 children belong to the Indigenous communities, which is equivalent to 4.6\% (Fundación Interamericana, 2011).

In addition, the long period of civil war and violence in Colombia has caused the displacement of many families from rural and Indigenous communities. According to the United Nations Refugee Agency (Alto Comisionado de las Naciones Unidas para los Refugiados, n.d.), 3,000,000 persons were displaced, of whom approximately 70,000 were Indigenous. Remarkably, displacement peaked relatively recently: Official figures report that between 2006 
and 2008, 48,318 members of Indigenous communities were displaced. The result is that a significant percentage of the Indigenous population is now settled, permanently or temporarily, in Colombia's cities, especially Bogotá, Medellin, and Cali.

These circumstances define a social context that represents a great challenge to both the government and the people, since it is difficult to create conditions for equal participation in debate and dialogue around the idea of children's “integral development.” In addition, the Modalidad Propia e Intercultural was designed for children living within their Indigenous communities, not for children whose families have been displaced to an urban setting.

Moreover, the state's policies are ambiguous when it comes to children under 3 years of age, since initial education is proposed for children over 3, while institutional care is offered from birth to 6 years. This leaves ambiguity about what should happen in the institutions of care during the first three years.

\section{The "quality" of institutional childcare}

Research on young children's involvement in institutions of early care has begun in several countries. In general, this research explores the consequences these institutions can have on children's psychological development. This research has been influential, including in Colombia. However, in our opinion, several difficulties confront the interpretation of its findings.

The most influential studies are those that emphasize evaluation of "quality" Peter Moss and Gunilla Dahlberg (2008) explain that quality is assumed to be "an attribute of services for young children that ensures the efficient production of predefined, normative outcomes, typically developmental or simple learning goals" (p. 3). Studies focus on what are taken to be indicators of institutional quality: the adult-child ratio, the conditions of the classrooms and the building, the number and character of adult-child interactions, and the pedagogic curriculum. These are certainly factors intrinsic to the functioning of these institutions, but these studies assume that child development experts have identified universal, objective norms that define a program's quality. However, there is every indication that definitions of quality are based on what specific cultural groups privilege in their own way of life. Generally, researchers define quality in terms of middle-class standards. In addition, outcomes are typically measured in terms of subsequent school attainment, or using scales, instruments, and questionnaires whose validity is presumed because they have been standardized across different settings.

However, the norms that underlie evaluations of quality are not essential, natural, or neutral. Quality cannot be assessed in an objective, technical, and apolitical manner. In a multicultural world, it is no longer acceptable to measure and judge all cultures by comparison with Anglo-American norms.

Nonetheless, the position that UNESCO has adopted regarding childcare is based on these studies evaluating quality, and Colombian childhood policies follow UNESCO guidelines. Studies that subscribe to evaluation of quality in childcare institutions look for beneficial effects that quality programs can have on the socio-emotional and cognitive development of children (e.g., Bradley, McKelvey, \& Whiteside-Mansell, 2011; Landry et al., 2014; Sosinsky \& Kim, 2013; Sylva \& Pugh, 2011; Sylva et al., 2011; Thomason \& La Paro, 2009). For example, studies conclude that quality early care can facilitate cognitive and language development and social relationships, improve relationships between children and their mothers, and in general lead to long-term positive outcomes in the development of children (Babchishin, Weegar, \& Romano, 2013).

High-quality childcare is found to be associated with better cognitive, academic, and behavioural performance when the children are older (Vandell et al., 2010). More broadly, UNESCO (2012) has reported evidence for positive outcomes from young children's participation in high-quality childcare, arguing that this favours better 
school performance and the development of skills for future employment.

There are also warnings about the negative consequences of institutional care for very young children. For example, it has been suggested that institutional care for prolonged periods of time during the first two years of life can have adverse consequences on children's behaviour (Belsky et al., 2007; Jacob, 2009; National Institute of Child Health and Human Development, 2004, as cited by Eryigit-Madzwamuse \& Barnes, 2013). It has been suggested that institutional care before 2 years of age creates risk for subsequent emotional problems, as group contexts make it difficult for children to develop skills to deal with frustration (Eryigit-Madzwamuse \& Barnes, 2013; Stein et al., 2012).

Poor-quality childcare experiences have been associated with insecure attachment relationships with parents, regardless of the sensitivity of maternal care at home (Aviezer, 2008, as cited by Owen, 2018). At the same time, there are indications that the influence of parenting is stronger than the effects of institutional care (National Institute of Child Health and Human Development, 2006, as cited by Owen, 2018).

In Latin America, much research on early childcare has adopted a similar approach. For example, in Chile studies have indicated that, despite the massive enrollment of young children in these institutions, positive results are achieved only when quality is maintained (Cárcamo et al., 2014). In Argentina, similar studies have indicated that early entry into childcare provides cognitive stimulation which favours cognitive skills later, in primary school (Caputo \& Gamallo, 2010).

What we find striking, and preoccupying, in this body of research is its tacit assumption that the primary purpose of early childcare should be the cultivation of the skills necessary for schooling and for certain ways of working in adult life. These studies assume that "education" (providing children with knowledge and skills) is the primary, or even the only, function of childcare institutions. When attention is paid to socio-emotional development, this too is viewed as a matter of "competences" that can be learned and taught. This assumption can be seen also in UNESCO's emphasis on the need to continue improving the quality and accessibility of institutional childcare and its articulation with other levels of the education system (UNESCO, 2012).

In addition, the results of these studies are interpreted within a narrow psychological framing, one that presupposes that the basic social organization is the nuclear family and that psychological development follows a single, universal pathway. There is no acknowledgement of cultural difference in psychological processes, of cultural variation in the trajectories of children's psychological development and practices of childcare, or of differences in the expectations and ways of life of the communities in which children develop.

In part, this is because this research generally lacks the multidisciplinary perspective that would enable it to explore the social, political, and cultural dimensions of institutionalized childcare. As a result, these studies place their primary emphasis on the interaction between adults and the young children they are caring for. By focusing narrowly on adult-child interaction, however, they ignore the social and cultural context and the political dimension of the state's policies and programs for children. There is certainly no acknowledgement of the line of critical thinking about developmental psychology which points to the ways it can regulate and impose values on women, families, and ethnic minorities (Burman, 2011; Callaghan, Andenaes, \& Macleod, 2015).

There is, we believe, a need to incorporate critical perspectives and alternative paradigms into analytical empirical research on care in early childhood (Bloch, 2010). It is our goal in the Colombian context to conduct and promote research on the childcare phenomenon that acknowledges the political character of evaluations of quality, is sensitive to culturally diverse contexts, and can foster debate about which policies can be designed and implemented with respect to the needs of specific cultural communities, rather than simply aiming to implement international 
standards.

\section{Institutionalization of young children's development}

We consider it important to conceptualize the growing prevalence of organized childcare for young children in ways that go beyond quality and outcomes. Specifically, we propose that it be thought of as "governmentalization" in Michel Foucault's sense. Foucault emphasized how states arrange the "government" of people as they act and live within institutions. He was thinking about government in a broad sense as "the way in which the conduct of individuals or groups might be directed: the government of children, of souls, of communities, of families, of the sick" (Foucault, 1982, p. 221).

We also follow Foucault in seeing the daily practices in institutions of care for young children as the normalization and discipline of these children's ontologies: constituting the kind of humans they become. The "corporality" of everyday institutional life, both for children and for adults, is crucial here. The state is in effect operating in profound ways on its youngest citizens through projects ostensibly concerned with hygiene, health, pedagogy, and the rhythms and routines of everyday life. In fact, however, these projects change who these children are.

Moreover, government is not something that occurs only through state institutions. Empirical research within an academic discipline also exercises government over children, families, and educators as it establishes the status of "experts" and the concepts and values that shape how caregivers think and how policymakers act (Bloch, 2000).

Equally, practices of government are not exclusively matters of state law or policy. Alongside policies, laws, and decrees are routine everyday practices that sustain institutional power just as effectively, and which can also be disputed just as effectively as can formal laws.

Thinking of the growth of institutions of early childcare in terms of government and ontology highlights their political, social, and cultural dimensions and takes us beyond the narrow focus on the interaction between adults and children. It also takes us beyond the narrow focus on educational quality, which assumes, as we have noted, that institutional childcare has a primarily educational function and so must be coordinated with children's future schooling.

These points imply that two different research agendas are needed. The first focuses on formal policies and the images of childhood they presuppose. For example, Ana Vergara (2015) has shown the existence of public policies regarding children in Latin America that mix a concern with social investment with a concern with children's rights. However, the rights that are recognized, or assumed, are in fact neither universal nor consensual (Magistris, 2016).

The second research agenda, equally important, focuses on the operation of government in the everyday practices of childcare institutions. It is necessary to investigate how state policies and parenting and community practices come together and clash in the dynamics of institutions for young children, and the consequences of this for the ontology of children and for the existence of their communities. This is not only a study of practices, for government also establishes the conditions for people's thoughts and feelings (Castro, 2010). Foucault saw government as a play of power, defined as action on the actions of another, in which agency and even resistance are central. Indeed, "government" neither destroys nor erases the capacity for agency; rather, it shapes particular kinds of agency. It is important to recognize that the creation of a state institution does not negate the possibility of resistance on the part of families, professionals, or communities (Valverde \& Levi, 2006).

The key difference between this second research agenda and the study of the implementation of policies from the 
perspective of quality evaluation is that it doesn't take for granted the official "knowledge" that supports and is supported by the government in an institution. It can thus explore the risks and tensions this official knowledge can create for members of minority communities.

Governmentalization, then, is a way of directing the agency, thoughts, feelings, and ways of being of the people who live and work in an institution. In the section that follows, we describe two research projects that fall within the second research agenda that we have described, in which we sought to understand the government of young children in institutions by focusing on conflict and resistance on the part of those involved.

\section{Local knowledge: Two case studies}

In Colombia, government policies directed towards young children and their families are increasingly based on research evaluating the quality of childcare, both inside and outside the family home. Because these studies assume that there is a single, universal trajectory to psychological development, and because they use measures of outcomes and of quality that reflect, unconsciously, the values of a particular group, government policies tend to neglect cultural differences. Yet it has become clear that children's development follows trajectories that depend on their family and the culture of their community. Culture is a constitutive element in children's psychological development, and cultural diversity gives rise to distinct trajectories which integrate care practices, educational processes, and the place of the child in the lifeway of the community (Packer, 2017).

Furthermore, psychological development is not a solely epistemological process or a matter of acquiring or constructing practical and conceptual knowledge. It is also about becoming a particular kind of person, a member of the form of life of a community. These ontological considerations are attended to unreflectively by caregivers in every community. But Colombian government policies tend to focus on epistemological phenomena and treat childcare as though it is merely a form of education.

One way to track the changes that occur as government policies and practices of administrative and governmental management penetrate community institutions is to explore the work of those people who must implement these policies or practices, or whose work is directly impacted by them. Our research along these lines has been collaborative, participatory research. We have come to believe that it is crucial to generate local knowledge about the care and development of young children, based on an acknowledgment of our country's cultural diversity. This local knowledge is needed if Colombia is to have a solid basis upon which to design policies and programs for young children and is to implement them in appropriate ways.

The goal of generating local knowledge also requires reflection on the ways in which knowledge is produced, especially knowledge that acknowledges the singularity of contexts. For example, local knowledge cannot be based simply on the use of instruments whose presumed validity stems from their standardization across diverse cultural contexts.

\section{Voices from inside childcare institutions}

In this section we describe two examples of our own research in Colombia that has explored the phenomenon of the institutionalization of children under 2 years of age. The first project was carried out with professionals in charge of the care of young children in Cali (Ospina, Calderon, Quintero, Cantor, \& Villalobos, 2018). Cali is Colombia's third-largest city, with a population of around 2.5 million, located in the southwest of the country. It is the city with the greatest cultural diversity in Colombia. Around 600,000 Afro-descendants from the Pacific coast live in Cali, along with substantial numbers of at least six Indigenous groups: Ingas, Quichuas, Yanaconas, Misak, 
Kofan, and Nasa.

According to figures from the mayor's office of Cali, around 177,030 children aged 5 and younger lived in the city in 2017 (Alcaldía de Santiago de Cali, 2018). Various kinds of institutions offer care and food assistance to these children during the school day or for even longer hours, regulated by the government through public policies. They include public and private institutions, and they vary with the socioeconomic stratum in which they are located. These institutions have progressively incorporated practices of formal schooling, both pedagogical and administrative, such as organizing age-defined grades and hiring teachers who are licensed in early childhood education or preschool education.

Our investigation was conducted during 2016 and 2017 in collaboration with colleagues from the Universidad del Valle and Universidad ICESI. We undertook a form of participatory action research with a group of 13 early childhood workers from several public and private childcare institutions that represented different socioeconomic strata in Cali. We invited these early childhood professionals to participate in a learning group which we called a "training seminar." The teachers had to leave their work early in order to be able to attend the sessions with us, and to be granted permission they had to have a certification that their participation would count as a teaching qualification.

In regular meetings over a four-month period, totalling 90 hours, we engaged with these professionals in roundtable discussions and viewed and discussed videos they had made of everyday practical activities in their institutional settings. We sought to preserve the horizontality between researchers and participants. We emphasized their professional expertise and practical wisdom.

We asked these professionals to describe some of the tensions they experienced in their everyday responsibilities. It emerged that they were deeply concerned about the ways in which they were required to relate to the young children in their charge. They described conflicts they experienced carrying out daily tasks such as feeding, changing diapers, and responding to children's emotional needs, as they were required to do. For example, the type of food that children received was regulated, and there was strict monitoring of the amounts consumed. Juana described conflicts arising from the emotional bond with younger children:

A month ago there was a change in the kindergarten to move in groups, and they sent me to the nursery. I almost died, I started crying. I was anxious to create that bond with them, to work to be able to create it. Babies stick to one, and sometimes they just want to be with one and not with other people. From the outside they see it as easy, but when other teachers are there, they realize that it is not so easy.

This teacher had been working with older children when the institution asked her to work instead in the nursery. To "move in groups" means that the teachers rotated through the different grades. Juana described how working with the youngest children caused her a lot of anxiety, because she was not sure that she was prepared to meet the emotional demands that babies make. She pointed out that her colleagues "from the outside" see work with babies as a simpler task, but in fact it is a big challenge.

These professionals told us of administrative practices that seek to ensure they comply with government requirements concerning young children, who are considered vulnerable, and that they monitor children's attendance so that they do not lose their assigned place in the institution. The Colombian government has numerous reporting requirements for its planning and processes, as well as formal procedures to guarantee access to its programs. These requirements struck the teachers as inflexible. The institutions in which they worked had, following government policies, been placing increasing emphasis on "planning" (planeación): filling out worksheets in preparation for 
each class; defining the learning activities in which children would be involved. Indeed, the universities are now training early childhood "teachers" in these processes and practices of planning.

The following exchange took place during reflections over everyday routines:

Lucía: My work is not about teaching; it has to do more with cradling [acunar: to rock or cradle]. Sometimes the early childhood education practitioners arrive, and they come with a huge desire to carry out their planning. But cradling is not about planning.

Cecilia: In my case and in that of my companions, we plan, so as to comply, because it is a requirement.

Mariela: I feel that when I plan I am more focused on whether the planning is being carried out and not on whether the child enjoys what he is doing, in his game, in his relationship with others. But I see that they enjoy more when they have their free time.

Lina: At the beginning we had a lot of problems with this planning ... now I have learned how to handle it and I do not wear myself out so much. I turn in my planning as it is requested, very nice and well organized. But if what happens in the classroom is something else ... with the children one has to invent new things every day. If one tries to do everything said in the planning, one would not pay attention to the things that the children bring.

These professionals were finding ways to satisfy both the needs of the children, as they perceived them, and the requirements of the institutional setting.

Finally, they spoke of practices of human resource management in which university education and pedagogical training were privileged, rather than practical experience and competence. These professionals turned out to be very aware of the tensions, indeed contradictions, inherent in the fact that very young children need not only to be educated but also to be cared for. They spoke to us very clearly of their growing appreciation that a kind of childcare modelled solely on schooling is not appropriate, or even possible, for children who are so young. They emphasized the importance of recognizing the emotional needs of the younger children, and the type of care appropriate to these needs.

The following remarks were made while watching a video of nursery-aged children and their carer:

Lucia: I feel that it is a very home-like context: There are the cribs, the children are free to move around, the teacher is folding clothes, like the role of a mother. I see a teacher who cradles the children all the time, one after the other. She supports the children physically. In other words, she gives her body to the children; she releases them; she leaves them free. Very nice!

Coordinator: And what do you think of that?

Lucia: I like it. I think that the children are in a time of solitude, but they are accompanied and they may need those spaces. I feel that she is a teacher who cradles, who receives them through her cuddling.

The teacher's way of being with the children is valued, and there is no concern for the absence of explicit teaching. It is the similarity with home-not with school-that is remarked upon and praised. However, this "maternal role" was described as clashing with that of teacher, and was viewed both as less professional and less demanding:

Lina: It is usually thought that colleagues in formal school find the work more difficult and even that their work is more professional. It is thought that in the other levels you work, while we simply "mother" the children. 
We found diverse trajectories of formation among these professionals. Some were from university undergraduate programs in early education, while others were madres comunitarias, whose formal education consisted only of technical studies. Paradoxically, many of the university-educated professionals had come to feel that their theoretical and disciplinary knowledge was insufficient to enable them to make sense of their place as educators with babies and very small children. In fact, they voiced the concern that this academic knowledge could become an obstacle to identifying the needs of the children in their charge. A particular case of this was the difficulty they described in knowing how to relate to the children's parents and families, and how to respond to the diverse caretaking practices and values in the family.

Those professionals who had been madres comunitarias, on the other hand, whom one might have anticipated would feel legitimate in the eyes of the community, in fact felt devalued due to their lack of professional qualifications and the absence of academic validation.

The tensions we have described briefly here illustrate how these childcare professionals are torn between being the carers that they feel the children need and the teachers that are expected by the institution with its procedures and guidelines.

\section{The example of the Nasa and Luucx Lecxkwe}

These professionals working in institutions for young children in Cali were acutely aware of contradictions in their everyday routine practices. One might anticipate that the situation in an Indigenous community would be even more problematic. A research project conducted by a master's student (Grace David) of one of us (Tatiana) involved an ethnography of the Nasa community, focusing on a childcare institution that had been established by the state. Called Luucx Lecxkwe ("our children"), this institution was regulated by the same standards as the centres in Cali. But its practices were very different (David, 2018).

Cauca is a region to the southwest of Cali populated by Indigenous, Afro-descendants, and campesinos. The Nasa are an Indigenous community with around 60,000 to 80,000 members, many of whom live in a resguardo of 1,300 square kilometres in the highlands beside the Cauca valley. They are engaged in a struggle to regain territory in the valley which they believe was taken from them illegally early in the $20^{\text {th }}$ century.

This ethnographic study was carried out over two years, with weekly visits to the resguardo to understand how the Nasa implemented state programs to promote the development of their children. It is not possible for us to quote here the voices of the participants, since the access that was negotiated with the Nasa council (cabildo) granted us permission for local publication but not international publication.

Implementing the state's policies for Indigenous children in this community has not been a simple matter. It has taken ten years of dialogue between representatives of Bienestar Familiar, the government agency, and the cabildo. It was necessary for the community to become the legal operator, the administrator, of the state services. The Nasa maintained their opposition to intervention by expert professionals from the Western world, only permitting some professionals to enter and become involved in the care of their children after a collective evaluation of their spiritual suitability. They recognized the distance between what the government wanted to provide and the ways they raised their children, and they organized themselves to become, in a sense, intermediaries of the state in order to safeguard the principles of the Nasa world.

For the Nasa, a child's development is a matter of "walking towards the moon." This is not the achievement of skills or competencies, but an exploration of gifts given by nature before the child is born. The Nasa recognize a sacred relationship with nature and especially with the moon, which guides and influences everyday life: harvests, the 
care of animals, procreation, and the birth of children. The rhythms of the moon orient the gifts which children receive. These gifts must be discovered and fostered by the family and community, and they serve to maintain harmony and peace. The development of a child is a path of spiritual struggle which requires practices of spiritual protection for both the child and for those who accompany them.

The child development centre Luucx Lecxkwe does not operate in a closed space like the traditional preschool or kindergarten. The children go to various places in the community: to its rivers, its fields, and its forests. The Elders of the community (los abuelos, literally grandparents) decide on the activities in which the children participate. Mothers participate alongside their children, accompanied by state facilitators selected by the abuelos for their spiritual suitability and their knowledge of the Nasa language. The overall aim is to provide the care that will guide the discovery of each child's gifts. In short, every child is gifted.

The people who are in charge of the Nasa children are clear in their recognition of the needs of their children. For this community, the fundamental thing is to preserve their cultural identity, and this is what they seek to safeguard in the face of state interventions. This can be recognized in the following extract from field notes:

The children and parents of the program are sitting in a circle. The facilitator in the middle greets them in Nasa Yuwe and later speaks to them in Spanish about the importance of children living in the community, addressing the parents with the following words: "I am not the one who knows about pedagogy, it is you who know about pedagogy. Here we only come to remember what we are as Nasa, but you are the ones who know how to take care, you are the ones who know how to teach your children ... Here we are not going to teach formulas. It's about talking about what we are ... because as it is possible that we are of small stature, a nutritionist may tell us that our children have growth difficulties, when we the Nasa are that way! (David, 2018)

What community leaders seek to safeguard and legitimize is the community's continued existence. What is at stake is an ontological defence: They recognize that the proposed government programs would not simply teach the children, they would change who they are.

The intercultural collaboration behind the formation of Luucx Lecxkwe was possible because the community was able to maintain a symmetry of power with the state, and this generated the conditions for the community to sustain its own forms of government, those which they felt were legitimate for the preservation of their culture and the well-being of their children. However, the maintenance of this symmetry has required a posture of permanent resistance on the part of the community. The state had the best of intentions to protect Indigenous culture, but this in itself was not sufficient. The Nasa people had to both resist the state's interventions and be willing to engage in dialogue.

\section{Conclusions}

When the care of young children in institutions provided and regulated by the state is seen simply as a matter of education-of providing children with knowledge and skills that prepare them for school-this might seem to be of undoubted benefit to all. However, we have argued that in fact this institutional childcare is more than an epistemological matter. These institutions are also operating on an ontological level: Their "government" is shaping the kinds of person that these young children become. Viewed that way, it becomes evident that childcare institutions can clash with the pluricultural communities they claim to be serving. A single institution that is attended by children from multiple ethnic and cultural communities will struggle to do justice to all their ethnic and cultural identities. 
In the two examples we have summarized, it became evident that the phenomenon of institutionalization of the care of very young children is crisscrossed by a series of practices of administration, management, regulation, health, and hygiene with a logic and values that reflect a Western perspective oriented towards the constitution of schooled subjectivities, especially focused on the achievement of competences.

Creating and implementing effective and fair policy and programs for the care of young children from different cultures is a challenge in Colombia. This is not least because conceptions of cultural diversity and of integral development tend to clash. Globalized conceptions of integral development have generated a powerful model of parenting and childcare, but it is one that is displacing traditional childcare practices, and risks erasing the identities of Indigenous peoples. 


\section{References}

Alcaldía de Santiago de Cali. (2018). Subsecretaria de primera infancia. Informe de gestión 2017. Retrieved from http://www.cali.gov.co/ bienestar/publicaciones/139688/informe-de-la-subsecretaria-de-atencion-a-la-primera-infancia/

Alto Comisionado de las Naciones Unidas para los Refugiados. (nd). Perder nuestra tierra es perdernos nosotros: Los indígenas y el desplazamiento forzoso en Colombia. Retrieved from http://www.acnur.org/fileadmin/Documentos/RefugiadosAmericas/Colombia/ Los_indigenas_y_el_desplazamiento_forzoso_en_Colombia.pdf

Babchishin, L., Weegar, K., \& Romano, E. (2013). Early childcare effects on later behavioral outcomes using a Canadian nation-wide sample. Journal of Educational and Developmental Psychology, 3(2), 15-29. https://doi.org/10.5539/jedp.v3n2p15

Belsky, J., Burchinal, M., McCartney, K., Vandell, D. L., Clarke-Stewart, K. A., \& Owen, M. T. (2007). Are there long-term effects of early child care? Child Development, 78, 681-701. https://doi.org/10.1111/j.1467-8624.2007.01021.x

Bernal, R. (2014). Diagnóstico y recomendaciones para la atención de calidad a la primera infancia en Colombia. Cuadernos Fedesarrollo, 51. Retrieved from https://www.repository.fedesarrollo.org.co/handle/11445/148

Bloch, M. N. (2000). Governing teachers, parents, and children through child development knowledge. Human Development, 43, $257-$ 265. https://doi.org/10.1159/000022685

Bloch, M. N. (2010). Critical science and the history of child development's influence on early education research. Early Education and Development, 2(2), 95-108. http://dx.doi.org/10.1207/s15566935eed0202_2

Bradley, R. H., McKelvey, M. L., \& Whiteside-Mansell, L. (2011). Does the quality of stimulation and support in the home environment moderate the effect of early education programs? Child Development, 82(6), 2110-2122. https://doi.org/10.1111/j.14678624.2011.01659.x

Burman, E. (2011). Disciplines for and against psychology. Universitas Psychologica, 11(2), 645-662. https://doi.org/10.11144/Javeriana. upsy11-2.dfap

Callaghan, J., Andenaes, A., \& Macleod, C. (2015). Deconstructing developmental psychology 20 years on: Reflections, implications, and empirical work. Feminism \& Psychology, 25(3), 255-265. https://doi.org/10.11772F0959353515583702

Caputo, M., \& Gamallo, G. (2010). La calidad del jardín maternal y su influencia en el desarrollo cognitivo de los niños y niñas. Revista Latinoamericana para las Ciencias Sociales de la Niñez y la Juventud, 8(2), 849-860. Retrieved from http://www.redalyc.org/ pdf/773/77315155006.pdf

Cárcamo, R., Harriet, J., Vermeer, J., De la Harpe, C., Van der Veer, R., \& Van IJzendoorn, M. (2014). The quality of childcare in Chile: Its stability and international ranking. Child Youth Care Forum, 27(4), 457-477. https://doi.org/10.1007/s10566-014-9264-z

Castro, S. (2010). Historia de la gubernamentalidad: Razón de estado, liberalismo y neoliberalismo en Michel Foucault. Bogotá, Colombia: Siglo del Hombre Editores, Universidad Javeriana, Instituto Pensar, Universidad Santo Tomás.

Consejo Nacional de Política Económica Social, República de Colombia. (2007). Política pública para Primera Infancia. Documento Conpes social. Retrieved from https://www.mineducacion.gov.co/1759/articles-177832_archivo_pdf_Conpes_109.pdf

David, G. (2018). Ser niño Nasa en la institución de cuidado inicial Luucx Lecxkwe: Una aproximación etnográfica (Unpublished master’s thesis). Universidad del Valle, Cali, Colombia.

Eryigit-Madzwamuse, S., \& Barnes, J. (2013). Is early center-based child care associated with tantrums and unmanageable behavior over time up to school entry? Child \& Youth Care Forum, 42(2), 101-117. https://psycnet.apa.org/doi/10.1007/s10566-012-9193-7

Foucault, M. (1982). The subject and power. Critical Inquiry, 8(4), 777-795. Retrieved from https://is.muni.cz/el/1423/podzim2008/ SOC757/um/FOUCAULT_Subject_and_power.pdf

Fundación Interamericana (2011). Cuántos somos, cómo vamos. Diagnóstico sociodemográfico de Cali y 10 municipios del Pacífico nariñense. Cali, Colombia: Afroamérica XXI. Retrieved from https://www.dane.gov.co/files/censo2005/etnia/sys/cuantos_somos.pdf 
Instituto Colombiano de Bienestar Familiar. (2016). Manual técnico operativo. Servicio de Educación inicialen el marco de la atención integral para la primera infancia. Modalidad propia e intercultural para comunidades étnicas y rurales. Retrieved from https:// www.icbf.gov.co/sites/default/files/procesos/mo14.pp_manual_operativo_modalidad_propia_e_intercultural_v1.pdf

Jacob, J. I. (2009). The socio-emotional effects of non-maternal child care on children in the USA: A critical review of recent studies. Early Child Development and Care, 179, 559-570. https://doi.org/10.1080/03004430701292988

Landry, S. H., Zucker, T. A, Taylor, H. B., Swank, P. R., Williams, J. M., Assel, M., Crawford, A., Huang, W., Clancy-Menchetti, J., Lonigan, C. J., Phillips, B. M., Eisenberg, N., Spinrad, T. L., de Villiers, J., De Villiers, P., Barnes, M., Starkey, P., \& Klein, A. (2014). Enhancing early childcare quality and learning for toddlers at risk: The responsive early childhood program. Developmental Psychology, 50(2), 526-541. https://doi.org/10.1037/a0033494

Magistris, G. (2016). El gobierno de la infancia en la era de los derechos (Unpublished doctoral dissertation). Universidad de Buenos Aires, Argentina.

Moss, P., \& Dahlberg, G. (2008). Beyond quality in early childhood education and care: Languages of evaluation. New Zealand Journal of Teachers'Work,5(1),3-12.Retrievedfromhttp://citeseerx.ist.psu.edu/viewdoc/download?doi=10.1.1.551.1316\&rep=rep1\&type=pdf

Ospina, V., Calderon, T., Quintero, M., Cantor, J., \& Villalobos, M. (2018). Tensiones y debates sobre el rol del educador del nivel maternal. Cali, Colombia: Universidad de San Buenaventura. Universidad ICESI.

Owen, M. T. (2018). Child care and the development of young children (0-2). Encyclopedia of Early Childhood Development. Academy Press.

Packer, M. (2017). Child development: Understanding a cultural perspective. London, UK: SAGE.

Sosinsky, L. S., \& Kim, S. (2013). A profile approach to child care quality, quantity, and type of setting: Parent selection of infant child care arrangements. Applied Developmental Science, 17(1), 39-56. http://dx.doi.org/10.1080/10888691.2013.750196

Stein, A., Malmberg, L., Leach, P., Barnes, J., Sylva, K., \& The FCCC Team. (2012). The influence of different forms of early childcare on children's emotional and behavioural development at social entry. Child: Care, Health, and Development, 39(5), 676-687. https://doi.org/10.1111/j.1365-2214.2012.01421.x

Sylva, K., \& Pugh, G. (2011). Transforming the early years in England. Oxford Review of Education, 31(1), 11-27. https://doi. org/10.1080/0305498042000337165

Sylva, K., Stein, A., Leach, P., Barnes, J., Malmberg, L. E., \& The FCCC Team. (2011). Effects of early child-care on cognition, language, and task-related behaviours at 18 months: An English study. British Journal of Developmental Psychology, 29, 18-45. https://doi. org/10.1348/026151010X533229

Thomason, A. C., \& La Paro, K. M. (2009). Measuring the quality of teacher-child interactions in toddler child care. Early Education and Development, 20(2), 285-304. http://dx.doi.org/10.1080/10409280902773351

UNESCO. (2012). EFA global monitoring report: Expanding equitable early childhood care and education is an urgent need. Retrieved from http://unesdoc.unesco.org/images/0021/002160/216038E.pdf

Valverde, M., \& Levi, R. (2006). Gobernando la comunidad, gobernando a través de la comunidad. Delito y Sociedad, 1(22), 5-30. https:// doi.org/10.14409/dys.v1i22.5342

Vandell, D., Belsky, J., Burchinal, J., Vandergrift, N., Steinberg, L., \& NICHD Early Child Care Research Network. (2010). Do effects of early child care extend to age 15 ? Results from the NICHD study of early care and youth development. Child Development, 81(3), 737-756. https://doi.org/10.1111/j.1467-8624.2010.01431.x

Vergara, A. (2015). Public policy discourses on childhood during Chilean post-authoritarian democracy: A case of discursive colonization by the language of the free market. Childhood, 22, 4, 432-446. https://doi.org/10.1177\%2F0907568214549079 